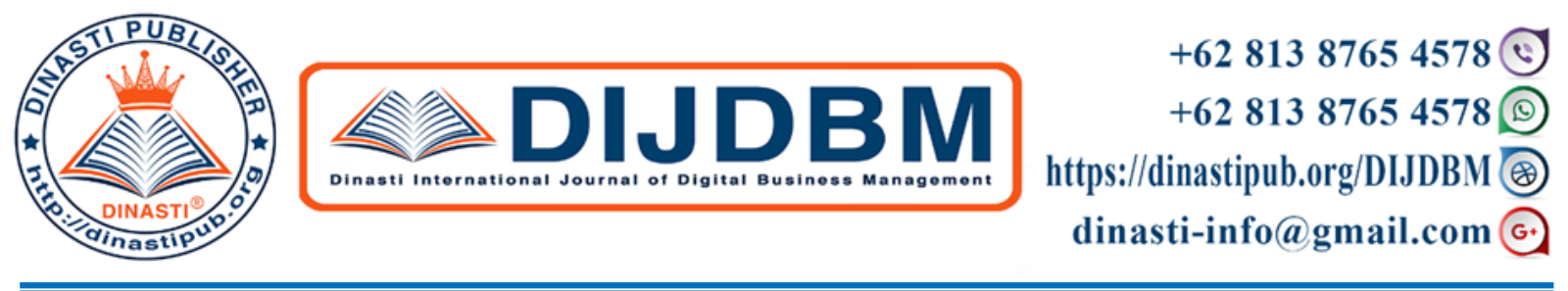

\title{
ANALYSIS OF EFFECT PRICE AND QUALITY ON BRAND IMAGE AND ITS IMPLICATION ON PURCHASE DECISION MODENA GAS COOKTOP (CASE STUDY ON GRAND GALAXY CITY RESIDENCE BEKASI)
}

\author{
Muhammad Thariq Nahra Putra, ${ }^{1}$ Adi Nurmahdi ${ }^{2}$ \\ 1)PT. Modena Indonesia. \\ ${ }^{2)}$ Magister Manajemen, Universitas Mercu Buana, Jakarta, Indonesia.
}

ARTICLE INFORMATION

Received: $22^{\text {nd }}$ July 2020

Revised: $5^{\text {th }}$ August 2020

Issued: $22^{\text {nd }}$ August 2020

Corresponding author: First

Author

E-mail:

thariqnahra@gmail.com adi.nurmahdi@mercubuana.ac.id

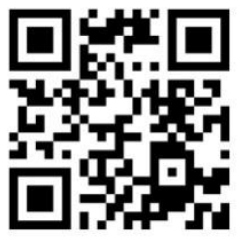

DOI:10.31933/DIJDBM
Abstract: This study aims to determine the effect of price and quality on brand image and its implications for purchasing decisions on Modena gas cooktops. This study also examines the indirect effect of price and quality on brand image with purchasing decisions as an intervening variable. The study was conducted in the grand galaxy city residence in Bekasi. The sample in this study is consumers or at least know about Modena products with a purposive sampling method. The number of respondents who participated in this study were 100 respondents. Data collection was done through a questionnaire with a Likert scale of 1-5. The method of analysis uses path analysis using SPSS version 24.0. the results showed that price has a positive and significant effect on brand image, quality has a positive and significant effect on brand image, brand image has a positive and significant influence on purchasing decisions for Modena gas cooktop. Price has a positive and significant influence on purchasing decisions, quality has a positive and significant influence on purchasing decisions. Price and quality simultaneously have a positive and significant influence on brand image. Price and quality of brand image simultaneously have a positive and significant influence on purchasing decision

Keywords: Price, Quality, Brand Image, Purchasing Decision, Gas Cooktop.

\section{INTRODUCTION}

Competition in the primary field of household goods, especially gas cooktops, causing employers should have the best strategy and appropriate to consider conditions in which the company. Modern society nowadays prefer a gas stove for cooking after setby the government 
to shift usage to the oil burner gas stove in 2007, assuming that the LPG is more economical than kerosene.

There are several examples of cooktops, including kerosene, electric cooktop, or gas cooktop. One of cooktop that currently many users are gas stoves. PT. Modena Indonesia is one of companies engaged in the field of household product needs by carrying Modena name as a trademark. Modena is one of many brands of gas cooktop that is sold freely in the Indonesian market.

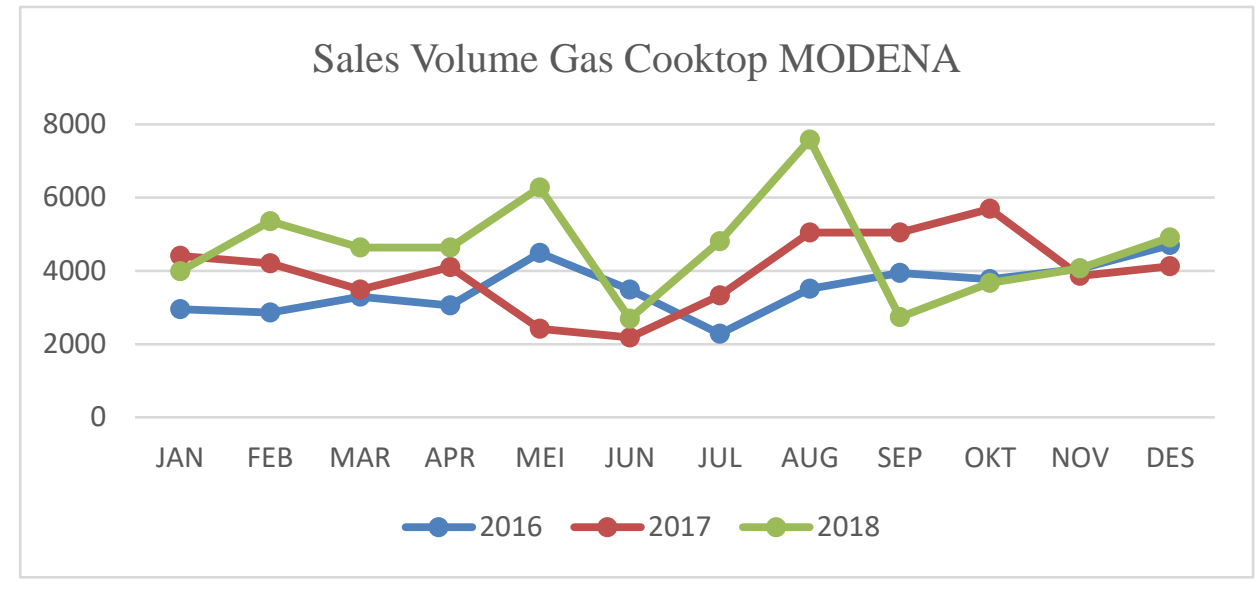

Figure 1. Sales Volume Gas Cooktop MODENA

Based on data from Figure 1 sales volume of Modena gas cooktops tends to fluctuate each month, but the quantity sold increases per each year. It is suspected that the possibility of prospective Modena customers turning or switching to other products. Modena since its establishment was first committed to providing household equipment, especially gas cooktops, by targeting the market and target consumers with middle and upper income. Therefore, to find out factors influence up and down sales volume gas stove, the researchers used historical data from the preliminary survey with the aim of wanting to find out variables caused the up and down of sales of gas cooktops PT. Modena Indonesia. Researchers conducted a pre-survey related to these preferences. This pre-survey was carried out in the Grand Galaxy City Housing area of Bekasi City and involved 30 respondents; each respondent was asked to choose what factors influenced them in the purchase decision of a product.

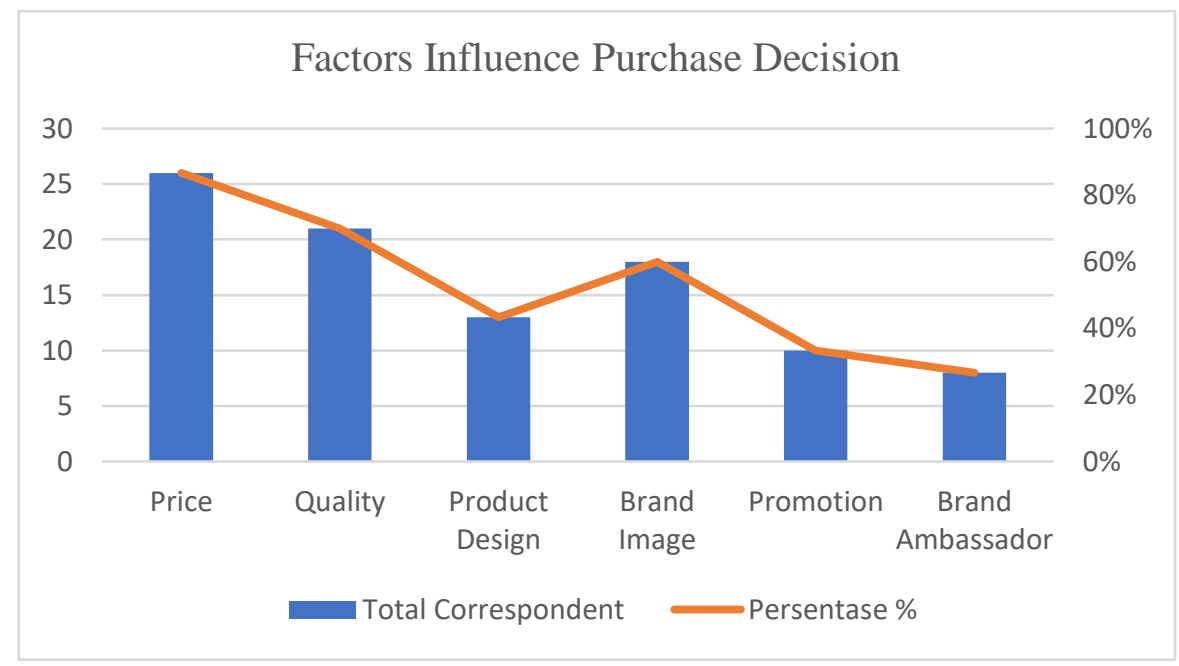

Figure 2. Factors Influencing Purhasing Decisions 
From pre-survey results as shown in figure 2 shows that there are 3 main factors that are thought to influence consumer purchasing decisions on Modena gas cooktop products, Price (83\%), Quality (70\%), Brand Image (67\%). The data shows that consumers' assessment and purchasing decisions on gas cooktop products are believed to be influenced by these three factors, which could be a factor in the up and down in sales and market share of gas cooktop, especially in Bekasi City. Based on this background, the authors are interested in conducting research with the title "Analysis the Effect of Price and Quality on Brand Image and Implications on Purchase Decision of Modena Gas Cooktop" (Case Study on Consumers of Grand Galaxy City Residence in Bekasi).

\section{LITERATUR REVIEW}

Price. Price definition according to Hawkins and Mothersbough (2013), "price is the amount of money one must pay to obtain the right to use the product," or means price is the amount of money that must be paid to get the right to use a product. Initially, price history was determined through negotiations between buyers and sellers. "Bargaining" is still common in some areas. According to Kotler \& Armstrong (2013), the company's decision in determining prices is influenced by two main factors, namely the company's internal factors and external environmental factors. These factors are: Internal Company Factors, consisting of four factors, namely: (1) Marketing Objectives. (2) Marketing Mix Strategy. (3) Costs. (4) Organizational Considerations. External Environmental Factors, consisting of three factors, namely: (1) The market and demand. (2) Competition. (3) Other external factors such as economic conditions and government intervention.

Quality. According to Tjiptono \& Chandra (2011), the concept of quality is considered as a measure of perfection of a product or service consisting of design quality and conformance quality. Product quality is a specific function of a product or service, conformity quality is a measure of how much the level of conformity between a product or service with quality requirements or specifications that have been set previously. The definition of product quality according to Kotler \& Armstrong (2013) is "the ability of a product to perform functions, includes the product's overall durability, reliability, precision, ease of operation and repair, and other valued attributes" which means the ability of a product to demonstrate functions, it includes overall durability, reliability, accuracy, ease of operation and repairs as well as other product attributes.

Brand Image. Hasan (2013) argues that a brand is interpreted as a combination of a name, sign, symbol or design to identify goods and services from a business or business group that is developed into a trademark and distinguishes itself from competitors, creates influence and produces value for the company. Many also refer to as design, color, motion, or a combination of other product attributes that give identity and differentiation to competitors' products. Brand image is a perception of a brand that is in the memory of consumers. Thus, the brand image does not exist in the features, technology or in the product itself, but something brought about by the advertisements, promotions or users of the product itself. Brand image is often used as extrinsic cues when consumers evaluate a product before deciding on a purchase intention (Wang and Tsai, 2014).

Buying decision. according to Setiadi (2010), the essence of consumer decision making (consumer decision making) is an integration process that combines knowledge to evaluate two or more alternative behaviors and choose one of them, whereas (Kotler, 2012), purchasing decisions are actions of consumers to want buy or not against the product. According to Kotler and Keller (2007), the purchase decision making process consists of 5 (five) stages of the process (1) Problem Recognition. (2) Information Search. (3) Alternative Evaluation. (4) 
Purchase Decision. (5) Post Purchase Behavior. Marketers must monitor post-purchase satisfaction, post-purchase actions and use of post-purchase products.

\section{FRAMEWORK AND HYPOTHESIS}

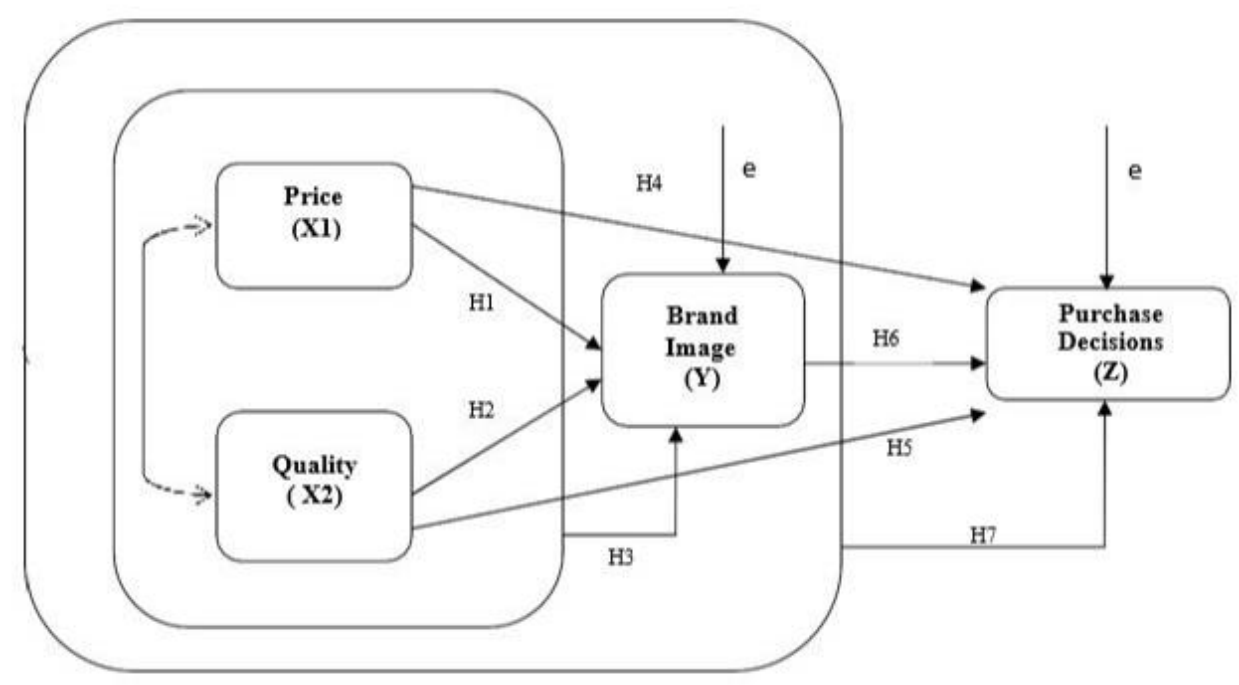

Figure 3. Framework

Hypothesis is a temporary answer to the formulation of a research problem. Based on the model of thinking above, a hypothesis can be made as follows:

H1 : Price, quality partially influences brand image.

H2 : Quality partially influences brand image.

H3 : Price, quality simultaneously influences brand image.

H4 : Price partially influences purchasing decisions.

H5 : Quality partially influences purchasing decisions.

H6 : Brand image partially influences purchasing decisions.

H7 : Price, quality, brand image simultaneously influences purchasing decisions.

\section{RESEARCH METHODS}

The study was conducted in grand galaxy city residence bekasi using purposive sampling method. The number of respondents who participated in the study were 100 respondents with criteria for gender, age, education level, occupation and income. Data collection was carried out through a questionnaire with a Likert scale of 1-5. The research variables used are as follows: (1) The independent variables are Price (X1) and Quality (X2), (2) The dependent variable is Brand Image (Y) and Purchase Decision (Z).

Analyst method uses a path analysis approach using SPSS version 24.0. Some of the tests carried out are (1) Test of research instruments, namely validity and reliability tests, (2) Classical Assumptions Test includes Normality, Multicollinearity and Heteroscedathicity Tests, (3) Hypothesis Tests include $\mathrm{T}$ Test (Partial Influence), $\mathrm{F}$ Test (Influence simultaneously), Determinant Coefficient Analysis (R2) and Correlation Test between dimensions and Path Analysis.

\section{RESULTS AND DISCUSSION}

Based on the results of the research analysis, validity test of all item questions regarding the research variables as many as 32 questions is valid because it shows the results of $r$ count 
greater than $\mathrm{r}$ tables. While the reliability test is known that all instruments in the study are reliable or can be trusted because it has a Cronbach's Alpha value ranging from above 0.6.

Table 1. Validity Test Result

\begin{tabular}{lcccc}
\hline Varible and Indicator & r Calculate & r Table & F. Value & Status \\
\hline Price (X1) & & & & \\
Indicator 1 & 0.595 & 0.196 & 0.000 & Valid \\
Indicator 2 & 0.771 & 0.196 & 0.000 & Valid \\
Indicator 3 & 0.619 & 0.196 & 0.000 & Valid \\
Indicator 4 & 0.388 & 0.196 & 0.000 & Valid \\
Indicator 5 & 0.659 & 0.196 & 0.000 & Valid \\
Indicator 6 & 0.518 & 0.196 & 0.000 & Valid \\
Indicator 7 & 0.658 & 0.196 & 0.000 & Valid \\
Indicator 8 & 0.698 & 0.196 & 0.000 & Valid \\
\hline Quality (X2) & & & & \\
Indicator 1 & & & & \\
Indicator 2 & 0.808 & 0.196 & 0.000 & Valid \\
Indicator 3 & 0.825 & 0.196 & 0.000 & Valid \\
Indicator 4 & 0.763 & 0.196 & 0.000 & Valid \\
Indicator 5 & 0.816 & 0.196 & 0.000 & Valid \\
Indicator 6 & 0.749 & 0.196 & 0.000 & Valid \\
Indicator 7 & 0.724 & 0.196 & 0.000 & Valid \\
Indicator 8 & 0.741 & 0.196 & 0.000 & Valid \\
\hline Brand Image (Y) & 0.720 & 0.196 & 0.000 & Valid \\
Indicator 1 & & & & \\
Indicator 2 & 0.766 & 0.196 & 0.000 & Valid \\
Indicator 3 & 0.732 & 0.196 & 0.000 & Valid \\
Indicator 4 & 0.762 & 0.196 & 0.000 & Valid \\
Indicator 5 & 0.851 & 0.196 & 0.000 & Valid \\
Indicator 6 & 0.664 & 0.196 & 0.000 & Valid \\
Indicator 7 & 0.778 & 0.196 & 0.000 & Valid \\
Indicator 8 & 0.658 & 0.196 & 0.000 & Valid \\
Purchase Decision (Z) & 0.629 & 0.196 & 0.000 & Valid \\
Indicator 1 & & & & \\
Indicator 2 & 0.710 & 0.196 & 0.000 & Valid \\
Indicator 3 & 0.535 & 0.196 & 0.000 & Valid \\
Indicator 4 & 0.649 & 0.196 & 0.000 & Valid \\
Indicator 5 & 0.660 & 0.196 & 0.000 & Valid \\
Indicator 6 & 0.727 & 0.196 & 0.000 & Valid \\
Indicator 7 & 0.610 & 0.196 & 0.000 & Valid \\
Indicator 8 & 0.674 & 0.196 & 0.000 & Valid \\
\hline & 0.634 & 0.196 & 0.000 & Valid \\
\hline & & & & \\
\hline & & & & \\
\hline & & & & \\
\hline
\end{tabular}

Based on table 1 the validity test on the variable items price, quality, brand image, and purchasing decisions of respondent's $n=100$ and the significance level of $5 \%$ with formula df $=\mathrm{n}-2$, the $\mathrm{r}$ table value obtained 0.196 . it can be concluded that the variable is valid, because $\mathrm{r}$ calculate value is greater than rtable so that the questionnaire can be used as a research instrument.

Table 2. Reliability Test Result 


\begin{tabular}{lcccc}
\hline \multicolumn{1}{c}{ Variable } & Cronbach's Alpha & N of items & $\begin{array}{c}\text { Cronbach's } \\
\text { Alpha Standard }\end{array}$ & Result \\
\hline Price (X1) & 0.755 & 8 & 0.6 & Reliable \\
Quality (X2) & 0.899 & 8 & 0.6 & Reliable \\
Brand Image (Y) & 0.874 & 8 & 0.6 & Reliable \\
Purchase Decision (Z) & 0.796 & 8 & 0.6 & Reliable \\
\hline
\end{tabular}

Normality test can be seen with Kolmogorov-Smirnov test on Tests of Normality table. If the data is normally distributed, value is significant in Kolmogorov-Smirnov column> 0.05. If the Sig. $<0.05$ then the data said to be not normally distributed. following normality test results are listed in table 3 and table 4

Table 3. Kolmogorov Smirnov Test Variable Dependen Brand Image

One-Sample Kolmogorov-Smirnov Test

\begin{tabular}{|c|c|c|}
\hline & & $\begin{array}{c}\text { Unstandardized } \\
\text { Residual }\end{array}$ \\
\hline N & & 100 \\
\hline \multirow[t]{2}{*}{ Normal Parameters ${ }^{a, b}$} & Mean & .0000000 \\
\hline & Std. Deviation & 2.19625101 \\
\hline \multirow[t]{3}{*}{ Most Extreme Differences } & Absolute & .098 \\
\hline & Positive & .098 \\
\hline & Negative & -.054 \\
\hline Test Statistic & & .098 \\
\hline Asymp. Sig. (2-tailed) & & $.068^{\mathrm{c}}$ \\
\hline
\end{tabular}

Table 4. Kolmogorov Smirnov Test Variable Dependen Purchase Decisions

One-Sample Kolmogorov-Smirnov Test

\begin{tabular}{|c|c|c|}
\hline & & $\begin{array}{l}\text { Unstandardized } \\
\text { Residual }\end{array}$ \\
\hline N & & 100 \\
\hline \multirow[t]{2}{*}{ Normal Parameters ${ }^{a, b}$} & Mean & .0000000 \\
\hline & Std. Deviation & 2.10917319 \\
\hline \multirow[t]{3}{*}{ Most Extreme Differences } & Absolute & .085 \\
\hline & Positive & .085 \\
\hline & Negative & -.049 \\
\hline Test Statistic & & .085 \\
\hline Asymp. Sig. (2-tailed) & & $.074^{\mathrm{c}}$ \\
\hline
\end{tabular}

Kolmogorov-Smirnov test results of models 1 and 2 show numbers of significance 
greater than 0.05 (> 5\%). This shows that regression model is normally distributed, so it can be further analyzed. Multicollinearity test aims to test whether in model regression found a correlation between independent variables. Regression model well its houldn't happen between free variables. In this research multikolinearitas symptoms views of the value of tolerance and Variance Inflation Factor (VIF). Multicollinearity test results can be seen in Table 5 below:

Table 5. Multicollinearity Test

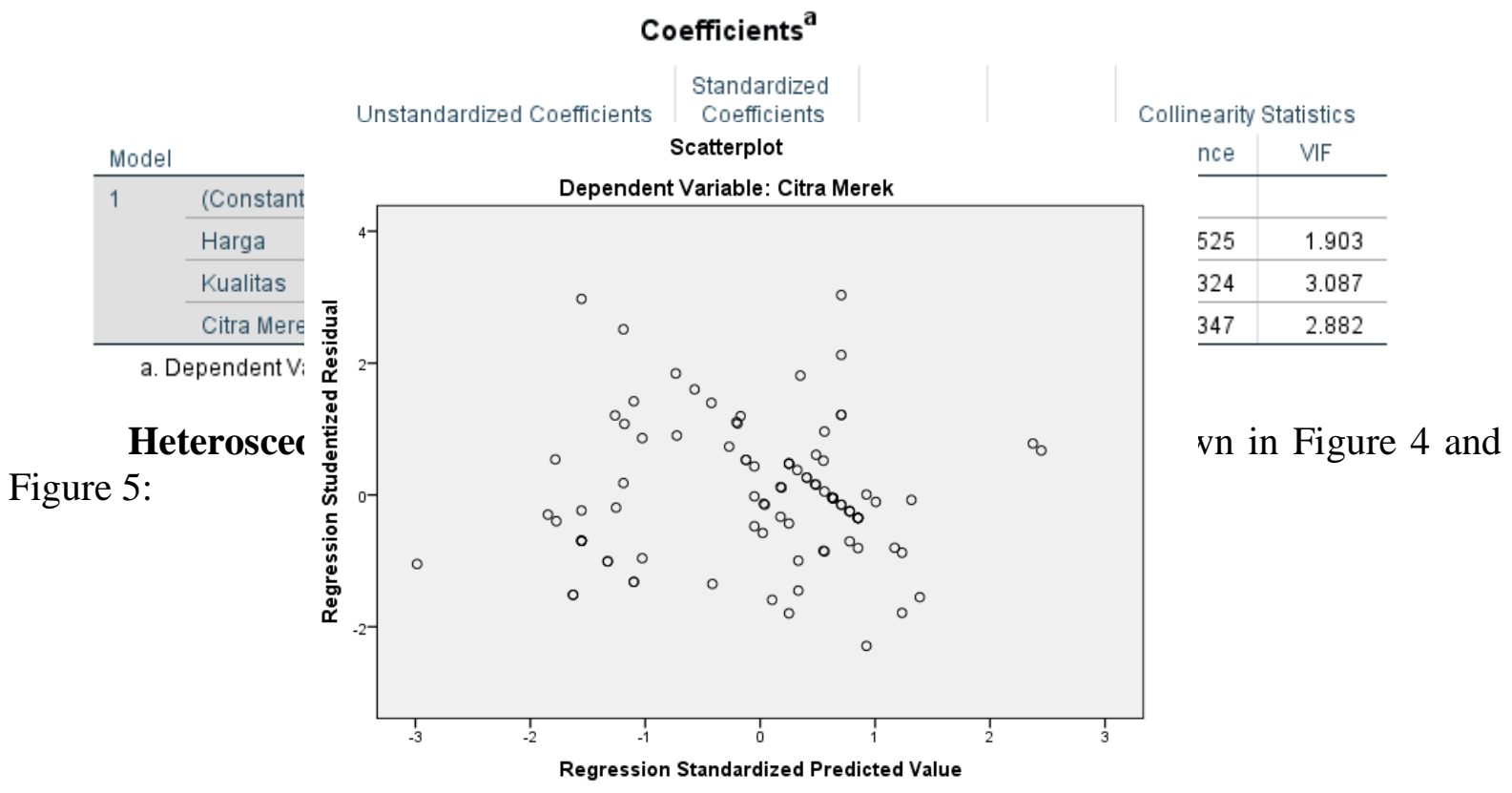

Figure 4. Scatterplot Heteroscedasticity Test Model 1

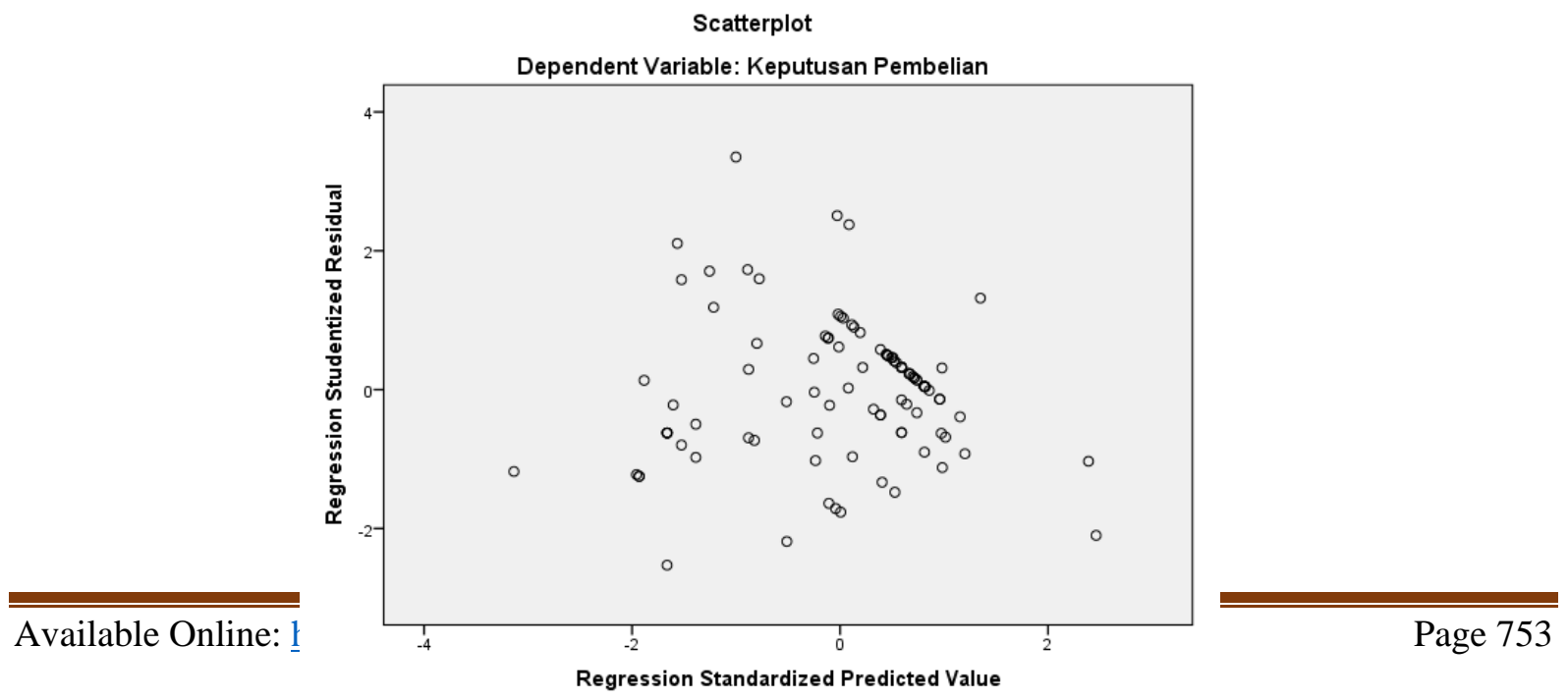




\section{Figure 5. Scatterplot Heteroscedasticity Test Model 2}

Based on Figures 4 and 5 heteroscedasticity test results show that the points spread above the number 0 (zero) and below the number 0 (zero). It can be concluded that the data in regression path of model 1 and model 2 do not experience heteroscedasticity problems, or the data has homocedasticity.

First Structure Model. This first structural equation is done through linear regression analysis which only considers the value of standardized coefficients.

Table 6. t Test Path Model 1 Coefficients

\begin{tabular}{cccc}
\hline Model 1 & Standardized Coefficients & t & Sig \\
\hline X1 & 0.190 & 2.373 & 0.02 \\
X2 & 0.669 & 8.334 & 0.00 \\
$\mathrm{R}^{2}$ & 0.653 & & \\
F & 91.253 & & 0.000 \\
\hline
\end{tabular}

a: Dependent Variable Brand Image (Y)

Based on Table 6 above, it can be concluded that the magnitude of the value of sig. $<$ from 0.05 so that the independent variable significantly influences the dependent variable. The independent variables used are Price (X1), Quality (X2) and the dependent variable brand image (Y). regression equation can be determined as follows:

\section{$\underline{Y 1=0.190 X 1+0.669 X 2+0.347}$}

1. Based on table 6, the coefficient results can be interpreted as follows: Effect of Price on Brand Image. The results of the analysis are the significant price effect on Brand Image, where the magnitude of influence seen from the value of Standardized Coefficient (beta) that is equal to 0.190 or $19 \%$.

2. Effect of Quality on Brand Image. Quality affects the Satisfaction of Brand Image, where the magnitude of influence can be seen from the Standardized Coefficient (beta) which is equal to 0.669 or $67 \%$.

Then in the F test, the value of R Square (R2) in the table is 0.653 where the number is used to see the effect of Price and Quality simultaneously on brand image that is $65.3 \%$. While the remaining $34.7 \%$ is influenced by other variables outside this model. Based on the F test results in this study obtained a sig of $0,000<0.05$, then the decision is $\mathrm{H} 0$ rejected and $\mathrm{H} 1$ accepted, meaning that the independent variables consisting of Price and Quality simultaneously affect the Brand Image. The magnitude of influence is $65.3 \%$ and the magnitude of influence outside other variables outside the regression is $34.7 \%$.

Second Structure Model. This second structural equation is done through linear regression analysis which only considers the standardized coefficients. 
Table 7. t Test Path Model 2 Coefficients

\begin{tabular}{cccl}
\hline Model 2 & Standardized Coefficients & $\mathbf{t}$ & Sig \\
\hline X1 & 0.186 & 2.130 & 0.03 \\
X2 & 0.393 & 3.530 & 0.00 \\
Y & 0.286 & 2.660 & 0.00 \\
$\mathrm{R}^{2}$ & 0.615 & & \\
F & 51.067 & & 0.000 \\
\hline
\end{tabular}

b: Dependent Variable Purchase Decisions (Z)

Berdasarkan Tabel 7 menunjukan besaran nilai koefisien setiap variabel independent yang digunakan, yaitu Harga, Kualitas dan Citra Merek. Dengan demikian persamaan regresinya dapat ditetapkan sebagai berikut:

\section{$\underline{Z=0,186 X 1+0,393 X 2+0,286 Y}$}

Based on these equations, it can be analyzed the effect of price, quality and brand image of each individual on purchase decision as follows:

1. Effect of Price on Purchasing Decisions. To see the effect of price on purchase decision, in this case the correspondence that already have or will purchase gas stoves planted with significance level of 0.05 with 100 respondents, the figures obtained t table of 1.9840. so that the tcount is obtained at 2.130> t table 1.9840, so $\mathrm{H} 0$ is rejected and $\mathrm{H} 1$ is accepted.

2. Effect of Quality on Purchasing Decisions. Quality influence on Purchasing Decisions with a significant level of 0.05 with the number of 100 respondents, the $t$ table 1.9840 is obtained, $\mathrm{t}$ count is 3,530>t table 1.9840, so $\mathrm{H} 0$ is rejected and $\mathrm{H} 1$ is accepted.

3. Effect of Brand Image on Purchasing Decisions. Influence of Brand Image on Purchase Decision by the significant level of 0.05 by the number of respondents 100 , it can be seen from the figure ttable 1.9840 , obtained t calculate equal to $2,660>\mathrm{t}$ table 1.9840 , so that $\mathrm{H} 0$ rejected and $\mathrm{H} 1$ accepted.

the $\mathrm{F}$ test, the value of $\mathrm{R}$ Square $\left(\mathrm{R}^{2}\right)$ on the test results amounted to 51.067 where $\mathrm{F}$ is the figure used to see the effect of price, quality and brand image simultaneously to the purchase decision. This means that Price, Quality and Brand Image have a simultaneous effect of $51.06 \%$ on the Purchasing Decision. While the remaining $48.94 \%$ is influenced by other variables outside this model.

Based on the results of $\mathrm{F}$ in this study obtained a sig value of $0,000<0.05$, and $\mathrm{f}$ arithmetic $>\mathrm{F}$ table (51.067> 1.39) then the decision is $\mathrm{H} 0$ rejected and $\mathrm{H} 1$ accepted, meaning that the independent variables consisting of Price, Quality and Brand Image simultaneously influence Purchasing Decisions. the magnitude of the effect is $51.06 \%$ and the magnitude outside the other variables outside the regression is $48.94 \%$.

The following are the results of the calculation of influence on the path analysis models 1 and 2 as shown in table 8 .

Table 8. Direct, Indirect and Total Influence

\begin{tabular}{|c|c|c|c|c|c|c|}
\hline \multirow{2}{*}{$\begin{array}{l}\text { Path } \\
\text { Model }\end{array}$} & \multirow[b]{2}{*}{ Hipothesis } & \multirow[b]{2}{*}{ Variable Influence } & \multicolumn{2}{|c|}{ Influence } & \multirow[b]{2}{*}{ Remain } & \multirow[b]{2}{*}{ TOTAL } \\
\hline & & & Direct & $\begin{array}{c}\text { Indirect } \\
\text { throught Y }\end{array}$ & & \\
\hline \multirow[t]{3}{*}{1} & H1 & $\mathrm{X} 1 \rightarrow \mathrm{Y}$ & 0.190 & & & 0.190 \\
\hline & $\mathrm{H} 2$ & $\mathrm{X} 2 \rightarrow \mathrm{Y}$ & 0.669 & & & 0.669 \\
\hline & $\mathrm{H} 3$ & $\mathrm{X} 1, \mathrm{X} 2 \rightarrow \mathrm{Y}$ & 0.653 & & 0.347 & 1 \\
\hline \multirow[t]{3}{*}{2} & $\mathrm{H} 4$ & $\mathrm{X} 1 \rightarrow \mathrm{Z}$ & 0.186 & 0.054 & & 0.24 \\
\hline & H5 & $\mathrm{X} 2 \rightarrow \mathrm{Z}$ & 0.393 & 0.191 & & 0.584 \\
\hline & H6 & $\mathrm{Y} \rightarrow \mathrm{Z}$ & 0.286 & & & \\
\hline
\end{tabular}


Table 8 can be seen that the influence of Price, Quality, partially and directly on Brand Image is positive and significant with a value of $0.190,0.669$. Variable quality has the greatest value among other variables. Next variable price and quality simultaneously also affects the image of the brand with a value of 0.653 . Furthermore, it is known that there is a significant influence between Price and quality on purchasing decisions directly, it shows that the effect of Price, Quality, Brand Image individually influences Purchasing Decisions. The influence of price and quality directly and positively and significantly influences the purchase decision with a total of 0.186 and 0.393 .

Based on the results of the study note that the relationship of the influence of Price, Quality indirectly on Purchase Decisions through Brand Image has a large enough value that is 0.054 and 0.191 . Then the variable Price, Quality and Brand Image simultaneously have a positive and significant influence on Purchasing Decisions with a value of 0.615. Figure 6 Illustrates empirical causal value between model 1 and model 2.

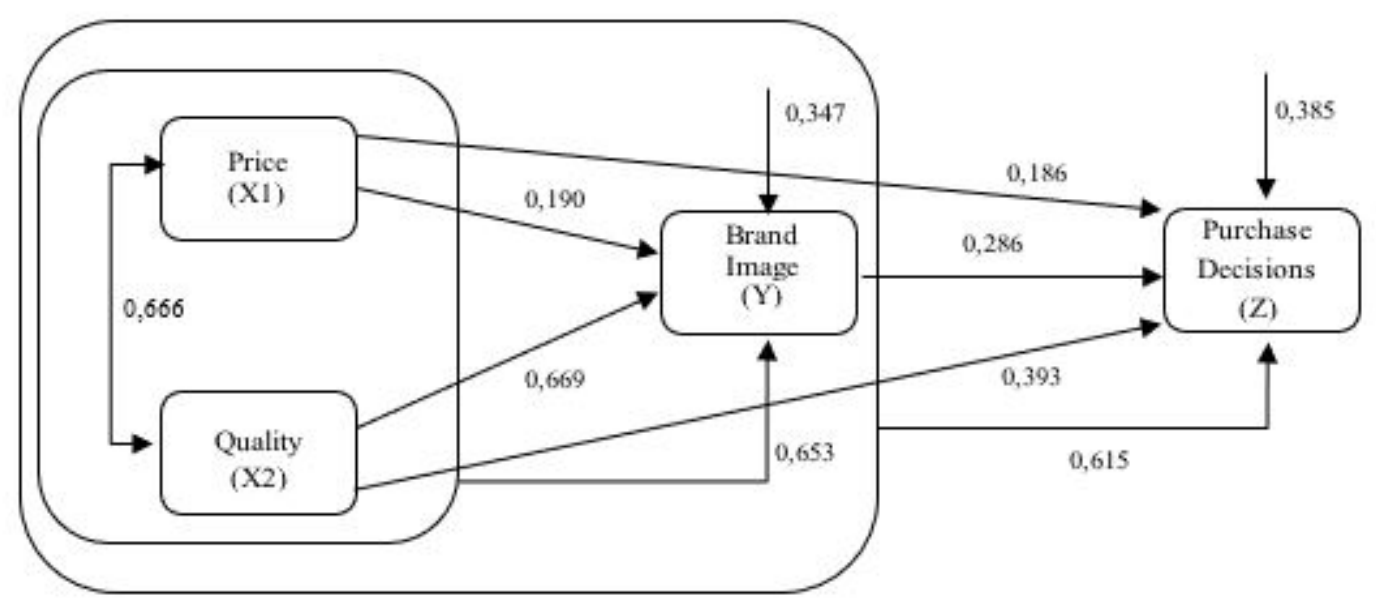

Figure 6. Empirical Causal path Model 1 dan Model 2

Correlation. To find out the level of strength of the relationship between each variable, a correlation test between variables is performed as seen in table 9 .

Table 9. Correlation Coefficient Between Variables

\begin{tabular}{|c|c|c|c|c|c|}
\hline \multicolumn{6}{|c|}{ Correlations } \\
\hline & & Price & Quality & $\begin{array}{l}\text { Brand } \\
\text { Image }\end{array}$ & $\begin{array}{l}\text { Purchase } \\
\text { Decisions }\end{array}$ \\
\hline \multirow[t]{3}{*}{ Price } & $\begin{array}{c}\text { Pearson } \\
\text { Correlation }\end{array}$ & 1 & $.666^{* *}$ & $.636^{* *}$ & $.630 * *$ \\
\hline & Sig. (2-tailed) & & .000 & .000 & .000 \\
\hline & $N$ & 100 & 100 & 100 & 100 \\
\hline \multirow[t]{3}{*}{ Quality } & $\begin{array}{c}\text { Pearson } \\
\text { Correlation }\end{array}$ & $.666^{* *}$ & 1 & $.795^{* *}$ & $.744 * *$ \\
\hline & Sig. (2-tailed) & .000 & & .000 & .000 \\
\hline & $\mathrm{N}$ & 100 & 100 & 100 & 100 \\
\hline \multirow[t]{2}{*}{$\begin{array}{l}\text { Brand } \\
\text { Image }\end{array}$} & $\begin{array}{c}\text { Pearson } \\
\text { Correlation }\end{array}$ & $.636^{* *}$ & $.795 * *$ & 1 & $.717 * *$ \\
\hline & Sig. (2-tailed) & .000 & .000 & & .000 \\
\hline
\end{tabular}




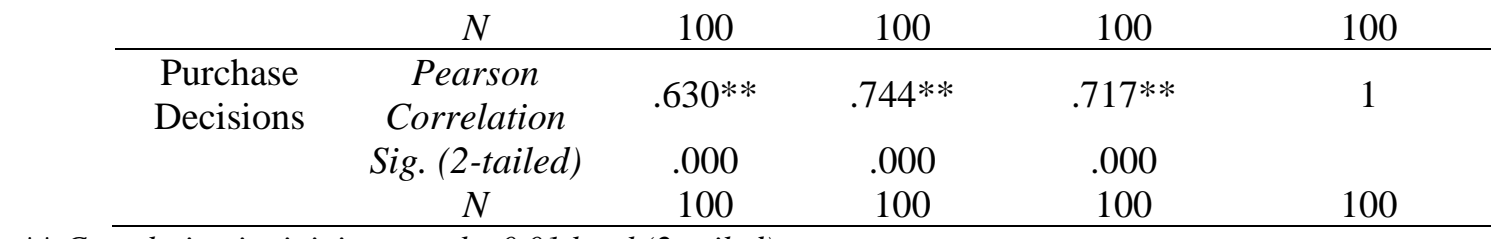

** Correlation is siginicant at the 0.01 level (2-tailed)

Based on Table 9, it can be interpreted that there is a correlation between price (X1) and Quality (X2) of 0666, the correlation of price (X1) and Brand (Y) equal to 0.636, the correlation Quality (X2) and Brand (Y) of 0795, Price correlation (X1) and Purchase Decision (Z) 0.630, correlation Quality (X2) and Purchase Decision (Z) of 0744, correlation Brand (Y) and Purchase Decision $(Z)$ of 0.717 . The correlation between above-mentioned variables are significant and in line because the numbers significance of each of these relations of 0000 or less than 0.05 and is marked with two stars. Correlation between dimensions. To find out which dimensions with a strong enough effect, a matrix is made that connects all dimensions between the independent variables, in this study, the data displayed are not as a whole (Full data can be seen in the appendix), shown in Table 10 as follows.

Table 10. Matriks Analysis Colleration Between Variable

\begin{tabular}{|c|c|c|c|c|c|c|c|c|c|c|}
\hline \multirow{3}{*}{ Variable } & \multirow{3}{*}{ Dimention } & & \multicolumn{4}{|c|}{ Brand Image } & \multicolumn{4}{|c|}{ Purchase Decisions } \\
\hline & & & \multicolumn{2}{|c|}{ Memorable } & \multicolumn{2}{|c|}{ Meaningful } & \multicolumn{2}{|c|}{$\begin{array}{l}\text { Personal } \\
\text { Factors } \\
\end{array}$} & \multicolumn{2}{|c|}{$\begin{array}{c}\text { Psychological } \\
\text { Factors } \\
\end{array}$} \\
\hline & & & Y1 & Y2 & Y3 & Y4 & $\mathrm{Z} 5$ & Z6 & $\mathrm{Z7}$ & $\mathrm{Z8}$ \\
\hline \multirow{8}{*}{ Price } & \multirow{2}{*}{ Affordable Price } & $\mathrm{X} 1.1$ & 0,21 & 0,216 & 0,403 & 0,425 & 0,315 & 0,149 & 0,288 & 0,305 \\
\hline & & $\mathrm{X} 1.2$ & 0,379 & 0,285 & 0,443 & 0,49 & 0,335 & 0,269 & 0,343 & 0,364 \\
\hline & \multirow{2}{*}{$\begin{array}{l}\text { Suitability price with } \\
\text { quality }\end{array}$} & $\mathrm{X} 1.3$ & 0,316 & 0,226 & 0,335 & 0,249 & 0,185 & 0,177 & 0,303 & 0,359 \\
\hline & & X1.4 & 0,126 & 0,229 & 0,305 & 0,215 & 0,202 & 0,144 & 0.1 & 0.004 \\
\hline & \multirow{2}{*}{$\begin{array}{l}\text { Suitability price with } \\
\text { benefits }\end{array}$} & $\mathrm{X} 1.5$ & 0.071 & 0,134 & 0,198 & 0,188 & 0,235 & 0,143 & 0,442 & 0,44 \\
\hline & & $\mathrm{X} 1.6$ & 0,147 & 0,416 & 0,221 & 0,249 & 0.084 & 0,145 & 0,265 & 0,38 \\
\hline & \multirow{2}{*}{$\begin{array}{l}\text { Suitability price with } \\
\text { ability }\end{array}$} & $\mathrm{X} 1.7$ & 0,295 & 0,183 & 0,233 & 0,302 & 0,29 & 0,237 & 0,416 & 0,442 \\
\hline & & $\mathrm{X} 1.8$ & 0,412 & 0,442 & 0,434 & 0,528 & 0,375 & 0,255 & 0,479 & 0,485 \\
\hline \multirow{8}{*}{ Quality } & \multirow{2}{*}{ Performance } & $\mathrm{X} 2.1$ & 0,375 & 0,373 & 0,401 & 0,448 & 0,443 & 0,418 & 0,586 & 0,576 \\
\hline & & $\mathrm{X} 2.2$ & 0,482 & 0,493 & 0,584 & 0,542 & 0,418 & 0,236 & 0,48 & 0,493 \\
\hline & \multirow{2}{*}{ keandalan } & $\mathrm{X} 2.3$ & 0,375 & 0,396 & 0,372 & 0,384 & 0,378 & 0,225 & 0,513 & 0,512 \\
\hline & & $\mathrm{X} 2.4$ & 0,426 & 0,475 & 0,528 & 0,588 & 0,498 & 0,295 & 0,489 & 0,462 \\
\hline & \multirow{2}{*}{ Specification } & $\mathrm{X} 2.5$ & 0,298 & 0,396 & 0,546 & 0,493 & 0,384 & 0,14 & 0,518 & 0,543 \\
\hline & & $\mathrm{X} 2.6$ & 0,17 & 0,421 & 0,439 & 0,301 & 0,251 & 0,063 & 0,578 & 0,567 \\
\hline & \multirow{2}{*}{ aesthetics } & $\mathrm{X} 2.7$ & 0,36 & 0,44 & 0,408 & 0,433 & 0,512 & 0,208 & 0,356 & 0,301 \\
\hline & & $\mathrm{X} 2.8$ & 0,346 & 0,418 & 0,448 & 0,454 & 0,489 & 0,218 & 0,331 & 0,303 \\
\hline \multirow{4}{*}{$\begin{array}{l}\text { Brand } \\
\text { Image }\end{array}$} & \multirow{2}{*}{ Memorable } & Y1 & & & & & 0,391 & 0,348 & 0,358 & 0,353 \\
\hline & & $\mathrm{Y} 2$ & & & & & 0,313 & 0,166 & 0,37 & 0,345 \\
\hline & \multirow{2}{*}{ Meaningful } & Y3 & & & & & 0,421 & 0,327 & 0,304 & 0,398 \\
\hline & & Y4 & & & & & 0,411 & 0,3 & 0,486 & 0,481 \\
\hline \multirow{3}{*}{$\begin{array}{l}\text { Purchase } \\
\text { Decisions }\end{array}$} & \multirow[b]{2}{*}{ Personal Factors } & $\mathrm{Z5}$ & 0,391 & 0,313 & 0,421 & 0,411 & & & & \\
\hline & & Z6 & 0,348 & 0,166 & 0,327 & 0,3 & & & & \\
\hline & Psychological Factors & $\mathrm{Z7}$ & 0,358 & 0,37 & 0,304 & 0,486 & & & & \\
\hline
\end{tabular}


Table 10 explains that the test results with the highest correlation between the variable price (price Conformity dimension with ability) to variable of brand image (dimensions meaningful) has a value of 0.528 . Meanwhile, the variable price (price suitability dimension with ability) to purchasing decision (dimensions of psychological factors) happened a strong correlation of 0.485 . Furthermore, variable quality (reliability dimension) to brand image (dimensions meaningful) happened a strong correlation of 0.588. In addition, variable quality (dimensions of performance) on purchase decisions (dimensions of psychological factors) there is also a strong correlation of 0.586 . means that the product has performed well and according to expectations when time usage. Based on the results of the study using path analysis, two sub-structures are obtained by discussing the results of the study as follows:

\section{Path Analysis Model I}

The first analysis shows that Price (X1) has a positive and significant effect directly on brand image (Y). this is in line with the results of previous studies conducted by Amron (2018), Panji Umar Wicaksono (2017) where prices partially have a significant effect on Brand Image. meaning that if the price of a product offered is in accordance with the ability of consumers, then the brand image of a product will be formed because it represents the desires of consumers.

The second analysis shows that Quality (X2) has a positive and significant effect on Brand Image (Y). This is in line with the results of previous research conducted by Andrianto, Hendra Noky dan Idris (2013) where product quality has a positive and significant effect on Brand Image. This means that product reliability is in line with consumer expectations, so consumers will always remember the brand that has provided reliability and satisfaction.

The third analysis shows that the variable Price (X1) and Quality (X2) together (simultaneously) has a positive and significant effect on Brand Image (Y). This is consistent with results of research conducted by Asep Septeri and Panji Umar Wicaksono (2018) who stated that Price and Quality had a positive and significant effect on Brand Image. In model 1 sub-structure, Quality is the most influential variable on Brand Image, followed by Price, so that in order to increase sales in the future, Modena must be able to maintain its product image in the form of a product that is modern, easy to operate, attractive colors and pay attention to product quality.

\section{Path Analysis Model II}

In the sub-structure of model 2, the fourth analysis can be seen that the variable price (X1) significantly influences the purchase decision (Z). this is in line with research conducted by Jackson R.S Weenas (2013) that consumers want competitive prices in terms of ability, whether the price offered is in accordance with the needs and capabilities provided by the product or not.

The fifth analysis shows that Quality (X2) has a significant effect on Purchasing Decisions (Z). this is in line with research conducted by Hadi Brata, Baruna; Shilvana Husani dan Hapzi Ali (2017) that consumers want to experience functional benefits when buying a product.

The sixth analysis shows that Brand Image (Y) is proven to have positive results and has a significant effect on Purchasing Decisions (Z). this is in line with research conducted by Aprianto Ronal (2016) that when in the social environment we are able to remember a brand quite well, eating will influence consumer purchasing decisions on a product because the surrounding environment recommends a brand that they remember to others.

The results of the seventh analysis showed that the price variable (X1), Quality (X2) and 
Brand Image (Y) together (simultaneously) had a positive and significant effect on Purchasing Decisions (Z). this is in line with research conducted by Amrulloh, Artika Romal dan Sasi Agustin (2016) that simultaneously price, product quality and brand image have a significant effect on purchasing decisions. Price suitability, perceived quality of the product, and a good brand image in the surrounding environment can change consumer purchasing decisions.

Based on the results of study show that Brand Image as an intervening variable (pathway) in path analysis is proven to have an impact on Purchasing Decisions as a result of influence of independent variable Price and Quality which can be interpreted that Brand Image can increase if Price and Quality are able to represent consumer desires, so that implications towards the Purchase Decision. From these 2 variables, in the path analysis model 2, one independent variable that has a significant effect is Quality (X2) so as to influence consumer purchasing decisions, the most appropriate way is to improve the quality of products offered so that they are in line with consumer expectations.

\section{CONCLUSION AND SUGGESTION Conclusion}

Based on the results of research and discussion Analysis Effect of Price and Quality and It's Implication on Purchase Decision Modena Gas Cooktop, several conclusions can be drawn, namely:

1. The results of the study found that price has a significant influence on brand image. This shows that consumers before deciding to buy a Modena gas cooktop compare and interpret in advance the price offered whether it is in accordance with the capabilities, benefits, reliability and quality.

2. It is proven that product quality variable has a significant influence on brand image of gas cooktoop. This shows that consumers want a product of highest quality. If quality of a product is good, then brand image will increase along with customer satisfaction with product quality.

3. It is proven that the brand image variable has a significant influence on the decision to purchase a gas cooktop. Consumers still assess brand image as a factor in buying a gas cooktop product. If brand image is good in the market, consumers will consider the purchase decision.

4. Proven that price has a significant effect on purchasing decisions. This indicates that price set by Modena, expensive or cheap can affect the purchase decision.

5. It is proven that quality has a significant effect on purchasing decisions. This indicates that quality is considered by consumers in purchasing gas cooktop products.

6. Price and quality variables simultaneously proved to have a significant effect on brand image. This condition is a logical consequence of a product offered and sold to consumers.

7. Variable price, quality and brand image simultaneously have a significant influence on purchasing decisions. This condition is a logical consequence of the accumulation of influence of price, product quality, brand image on purchasing decisions. The results showed that Modena's efforts in setting prices, guarding and offering highest quality products and creating a good brand image were able to influence consumer purchasing decisions for gas cooktop products.

\section{Suggestion}

Based on the results of research, analysis and discussion and conclusions that have been described, the researcher recommends the following points.

1. The results of study indicate that price influences the brand image especially on the suitability of prices with quality and benefits, where the results of respondents' assessment of Modena products as a whole are quite good but need to be developed and improved 
regarding price offered. There needs to be a review and analysis every month related to price of Modena gas cooktops products with other competitors.

2. In order for product quality to be maintained properly, response to customer complaints about the product must be improved by improving the quality of customer service so that quickly resolved, and there is product improvement to prevent repeated complaints from consumers. In this way, brand image will be maintained well in the eyes of consumers.

3. Modena must be able to maintain ibrand image as number 1 trademark in Indonesia for cooking category by improving verbal and visual communication in marketing its products.

4. So that companies can conduct comparative studies on competitors in the market each month regarding prices offered to consumers. Price is frontline in consumer purchasing decision factors.

5. So companies can produce gas cooktop products in terms of performance and specifications can influence consumer purchasing decisions.

6. So companies can determine a clear market segmentation by making a grouping or making a second brand related to the price and quality of a product because so far Modena is a brand of gas cooktop with middle and upper market segmentation.

7. To overall positive results of this study it is recommended that companies can always monitor and see the economic conditions of the purchasing power of consumers. then be able to consistently maintain quality of its products and after service services so that brand image formed so far will be well preserved and always be a determining factor in purchasing decisions

\section{REFERENCE}

Amron, Amron. 2018. "The Influence of Brand Image, Brand Trust, Product Quality and Price on The Customer's Buying Decision of MPV Cars". European Scientific Journal, Vol. 14 No. 13.

Arslan, Muhammad. 2014. "Impact of Brand Image and Service Quality on Consumer Purchase Intention". Research on Humanities and Social Scienses, Vol. 4, No. 22.

Andrianto, Hendra Noky dan Idris. 2013. "Pengaruh Kualitas Produk, Citra Merek, Harga, dan Promosi terhadap Keputusan Pembelian Mobil Jenis MPV Merek Toyota Kijang Innova di Semarang." Diponegoro Journal of Management. Vol 2, No 3, Hal 1-10.

Ali, Hapzi, Evi Narulita, Adi Nurmahdi. 2018. "The Influence of Service Quality, Brand Image and Promotion on Purchase Decision at MCU Eka Hospital." Suadi journal of Business and Management Studies. Vol. 3 Issue. 1

Amrulloh, Artika Romal dan Sasi Agustin. 2016. "Pengaruh Kualitas Produk, Harga, dan Citra Merek terhadap keputusan Pembelian Honda Beat." Jurnal Ilmu dan Riset Manajemen, Vol. 5, No 7.

Aprianto Ronal. 2016. "Pengaruh Brand Image Dan Word Of Mouth Communication Terhadap Keputusan Pembelian Kompor Gas Rinnai Pada Konsumen Kelurahan Cereme Taba Kota Lubuk Linggau." Jurnal Ilmiah Orasi Bisnis, Vol. 16. No 2.

Bian, Xuemei and Luiz Moutinho. 2011. The Role of Brand Image, Product Involvementand knowledge in Explaining Consumer Purchase Behavior of Counterfeits. European Journal of Marketing. Volume 45 (1). Hal 191-216.

Carunia Mulya Firdausy, Rani Idawati. 2017. "Effects of Service Quality, Price and Promotion on Customers purchase Decision of Traveloka Online Airline Tickets in Jakarta". International Journal of Management Science and Business Administration. Vol. 3, Issue 2, January 2017, Pages 42-49.

Fiani. Margaretha dan Edwin Japarianto. 2012. "Analisis Pengaruh Food Quality dan Brand Image Terhadap Keputusan Pembelian Roti Kecik Toko Roti Ganeps di Kota Solo.” Jurnal Manajemen Pemasaran Vol.1 No 1.

Ghozali, Imam. 2011. "Aplikasi Analisis Multivariate dengan Program SPSS”. Semarang: Badan Penerbit Universitas Diponegoro.

Gurleen, Kanwal and Pooja Bhandari. 2014. "Customer Satisfaction and Factors Influencing The 
Purchase Decision of Notebook Computers in Punjab." Journal Research in Marketing, Vol. 2, No.3 pp 205-211.

Hadi Brata, Baruna: Shilvana Husani dan Hapzi Ali, 2017. "The Influence of Quality Product, Price, Promotion and Location to Product Purchase Decision on Nitchi at PT. Jaya Swarasa Agung in Central Java”. Saudi Journal of Business and Management Studies. Vol. II, No.2, hal 433-445.

Istanita, Sukma. Et al. 2016. Pengaruh Green Marketing terhadap Citra Merek dan Keputusan Pembelian (Survei pada Produk Ramah Lingkungan Lampu Philips LEG di Perum Kepajen Permai 1. Rw 4, Desa Talangagung, Kec. Kapajen, Malang, Jawa Timur)”. Jurnal administrasi Bisnis (JAB) Vol. 32 No. Maret 2016.

Jackson R.S Weenas. 2013. "Kualitas Produk, Harga, Promosi dan Kualitas Pelayanan Pengaruhnya terhadap Keputusan Pembelian Spring Bed Comforta”. Jurnal Emba. Vo.11 No. 4. Desember 2013.

Kotler, Philip dan Gary Armstrong. 2013. Prinsip-Prinsip Pemasaran. Terjemahan Bob Sabran.

Kotler, Philip dan Kevin Lane Keller. 2012. Manajemen Pemasaran. Edisi 14. Erlangga. Jakarta.

Mehmood, Waqas and Owais Shafiq. 2015. "Impact of Customer Satisfaction, Service Quality, Brand Image on Purchase Intention". Jurnal of Marketing and Consumer Research, Vol. 15.

Monintja, Reimond Yohanes et al. 2013. "Analisis Merek, Promosi dan Harga pengaruhnya terhadap Keputusan Pembelian Gelael Swalayan Manado. Jurnal EMBA. Vol. 3 No. 4.

Schiffman, Leon G. and Leslie L. Kanuk. 2000. Consumer Behavior. Fith Edition Prentice-Hall Inc. New Jersey.

Uddin, Reaz, Nusrat Zahan Lopa dan Oheduzzaman. 2014. "Factors Affecting Customers' Buting Decisions of Mobile Phone: A Study on Khulna City, Bangladesh". International Journal of Managing Value and Supply Chains (IJMVSC) june 2014, Vol. 5, No. 2, PP 21-28.

Wicaksono, Usmar Panji. 2017. "Analisis pengaruh Kualitas Produk, Persepsi Harga, Promosi Terhadap Citra Merek dan Minat Beli Serta Dampaknya pada Keputusan Pembelian Kartu Perdana XL Axiata di Semarang”. Diponegoro Journal of Management. Vol.6 No. 2. Tahun 2017 Hal 1-11. 